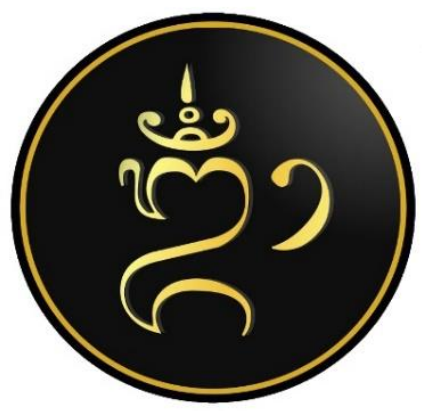

E-ISSN: $2722-8576$

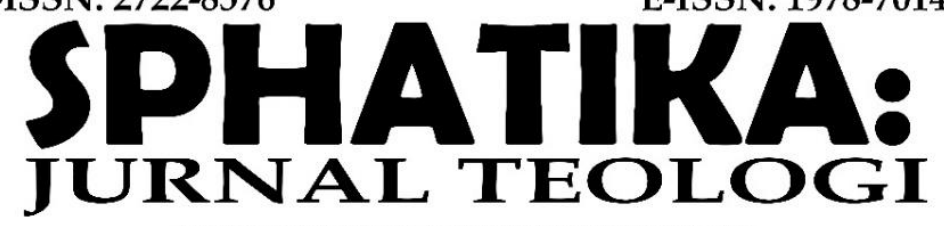

UNIVERSITAS HINDU NEGERI

I GUSTI BAGUS SUGRIWA DENPASAR

VOLUME 12 NOMOR 2, SEPTEMBER 2021

\title{
KONSEP ISTA DEWATA DALAM LONTAR BHUANA SANGKȘEPA: SOSIAL RELIGIUS HINDU DI BALI
}

\author{
Putu Eka Sura Adnyana ${ }^{1}$ \\ 1DPP Peradah Indonesia Bali \\ 1ekasuraadnyana@gmail.com
}

\begin{tabular}{l}
\hline Keywords: \\
Bhuana Sangksepa; \\
Hindu social \\
religion; Ista \\
Dewata
\end{tabular}

Kata kunci:

Ista Dewata;

lontar Bhuana

Sangkșepa; sosial

religius Hindu

\begin{abstract}
Hinduism in Indonesia, especially that which was inherited in Bali, is a combination of ancestral beliefs (pre-Hindu) with Vedic teachings that came to the archipelago and blended harmoniously to form sivasiddhanta in Bali. This paper uses two combined theories, namely the theory of hermeneutics, and the theory of symbolic interactionism. The method in collecting data uses the listen-to method, which is combined with basic note-taking techniques. followed by using data analysis methods and techniques which include (1) Data Reduction, (2) Data Presentation, and (3) Verification. It ends with the method of presenting the results of data analysis using an informal method. The text of the Lontar Bhuana Sangkșepa contains a dialogue between Bhațāra Siwa and Bhatāiri Uma accompanied by Bhațāra Kumara. Lontar Bhuana Sangksepa consists of 128 Sanskrit Slokas with Old Javanese language, the contents of which explain how to achieve kalepasan with the teachings of Yoga. The concept of the 33 Vedic Gods or what is known as Ista Dewata is transformed into the social religious practice of Hinduism in Bali with the pangider-ider or Dewata Nawa Saga. then those are the forms of grounding the Vedic teachings that can be seen in the practice of Hindu religious life in Bali.
\end{abstract}

\section{Abstrak}

Agama Hindu di Indonesia khususnya yang diwarisi di Bali adalah perpaduan antara keyakinan leluhur (pra Hindu) dengan ajaran Veda yang datang ke Nusantara dan menyatu dengan harmonis membentuk Śivasiddhanta di Bali. Tulisan ini menggunakan dua teori yang dipadukan, yaitu teori hermenutika, dan teori interaksionisme simbolik. Metode dalam pengumpulan data menggunakan metode simak, yang dikombinasikan dengan teknik dasar catat. dilanjutkan dengan menggunakan metode dan teknik analisis data yang meliputi (1) Reduksi Data, (2) Penyajian data, dan (3) Verifikasi. Diakhiri 
dengan metode penyajian hasil analisis data menggunakan
metode informal.Isi teks Lontar Bhuana Sangkșepa memuat
dialog antara Bhațāra Śiwa dengan Bhațāri Uma disertai dengan
Bhațāra Kumara. Lontar Bhuana Sangkșepa terdiri dari 128 Sloka
bahasa Sanskerta dengan bahasa Jawa Kuno, isinya pada
menjelaskan mengenai cara untuk mencapai kalepasan dengan
ajaran Yoga. Konsep 33 Dewa Veda atau yang dikenal Ista
Dewata ditransformasikan kedalam pelaksanaan sosial religius
Hindu di Bali dengan pangider-ider atau Dewata Nawa
Sañga.Interaksi simbol-simbol Ista Dewata tersebut yang
diaplikasikan pada pelaksanaan sosial religius Hindu di Bali
semua saling berpengaruh, berhubungan, dan melengkapi,
maka itulah bentuk-bentuk pembumian ajaran Veda yang
dapat dilihat pada praktik kehidupan beragama Hindu di Bali.

\section{PENDAHULUAN}

Agama Hindu merupakan agama yang tertua dan berasal dari India. Siwananda (2005:1) menjelaskan secara historis diketahui bahwa agama Hindu berasal dari India, pada awalnya berkembang di lembah Sungai Shindu dan hingga kini ajarannya berkembang ke seluruh dunia termasuk ke Indonesia (yang dahulunya bernama Nusantara). Ajaran Agama Hindu sangat fleksibel dan universal dapat menerima kearifan lokal daerah sehingga menyebabkan agama Hindu sangat mudah diterima oleh setiap orang. Walaupun Agama Hindu sebagai agama tertua di dunia, namun sistem ketatanegaraan Republik Indonesia baru mencatat Hindu sebagai agama yang resmi diakui keberadaannya di Indonesia pada tahun 1965 melalui KEPRES No. 1 Tahun 1965 dan UU No. 5 tahun 1969 (Ismail, 2016:3).

Agama Hindu di Indonesia khususnya yang diwarisi di Bali adalah perpaduan antara keyakinan leluhur (pra Hindu) dengan ajaran Veda yang datang ke Nusantara dan menyatu dengan harmonis membentuk Śivasiddhanta di Bali. Beberapa ajaran Veda seperti dalam Itihasa-Purāna, Darsana dan lain-lain ditulis kembali dalam lontar dan dikemas dengan bahasa Nusantara (bahasa Kawi). Disebut dengan mangjawakên byasa māta $\overline{1}^{1}$ yang berarti membahasajawakan ajaran Mahaåsi Byasa (Veda) (Zoetmulder, 1983). Dengan demikian ajaran Agama Hindu di Bali esensinya sama dengan esensi Veda. Dari Veda mengalir ajaran dalam berbagai-bagai bentuk pelaksanaan hidup beragama Hindu. Sosiokultural Bali menjadi media pelaksanaanya, akibatnya bentuk aktivitas keagamaan bervariasi.

Permasalah sekarang, muncul orang-orang (oknum) yang kurang memahami hal tersebut. Mengatakan bahwa agama Hindu di Bali hanya bersumber pada lontar, upacara

\footnotetext{
${ }^{1}$ Pada abad ke IX pada era Raja Sri Dharmawangsa Teguh di Jawa Timur, muncul sebuah gerakan yang diprakarsai oleh sang Raja yaitu 'Mangjawaken Byasamata', sebagai proyek besar-besaran kerajaan Kediri pada masa itu.
} 
agama dan mengatakan pemborosan materi serta menyimpang dari ajaran Veda, selanjutnya mengatakan back to Veda yaitu kembali ke Veda. Dengan menyalahkan beragama dengan tradisi masyarakat Bali, dan menganjurkan kembali mengikuti ajaran India (Veda secara utuh). Anggapan seperti itu sudah tentu tidak benar dan perlu di luruskan agar tidak terjadi konflik antara Hindu di Bali dengan Hindu yang menyebut ajarannya bersumber pada Veda yang murni. Sura (1994:10) menjelaskan sesungguhnya pustaka suci Agama Hindu adalah Veda, mengalir luas berpadu dengan kearifan lokal setempat, maka wajahnya berubah sesuai dengan ruang dan waktu yang dilaluinya, tetapi esensinya tetap esensi Veda.

Segala aktifivas sosial religius ( $\bar{a} c \bar{a} r \bar{a})$ Hindu di Bali bersumber dan selalu merujuk pada pustaka suci Veda. Misalnya pada banten sarad, pulegembal, lis, banten caru, tawur dan lain sebagainya. Semuanya merujuk pada kemahakuasaan Ida Sang Hyang Widhi Wasa yang bermanifestasikan pada Ista Dewata. Jika Merujuk pada hasil penelitian yang dilakukan Max Muller (Sura, 2014; Surada, 2020:37) jumlah ista dewata sebanyak 33 dewa dan terbagi atas 3 kelompok yang terdiri II dewa untuk tiap-tiap wilayah kekuasaan dunia, angkasa, dan surga. Hal ini terdapat dalam kitab suci Rg Weda dan Atharvaveda. Di Nusantara khususnya umat Hindu di Bali, konsep Ista Dewata tercantum dan bertransformasi pada sumber lontar Bhuana Sangkșepa. Lontar Bhuana Sangkșepa merupakan lontar yang bersifat tutur.

Tutur merupakan salah satu jenis sastra yang mengandung nilai filsafat, agama, dan nilai kehidupan. Istilah tutur di Bali sering disamakan dengan satua (cerita). Istilah Tutur memiliki pengertian yang sangat luas. Zoemulder (2004:1307) menjelaskan bahwa kata tutur berarti daya, ingatan, kenang-kenangan, kesadaran, sedangkan dalam kamus Bahasa Bali Indonesia (Warna dkk, 1991:757) kata tutur berarti nasihat atau cerita. Singkatnya, lontar tutur Bhuana Sang Kșepa isinya menjelaskan konsep Ista Dewata dalam dunia ini. Ista Dewata sebagai penyangga alam semesta, dan Ista Dewata sebagai penggerak alam semesta.

Berdasarkan pemaparan diatas sangat menarik memahami konsep Ista Dewata dalam lontar Bhuana Sangkșepa. Terutamanya sebagai suatu tinjauan pelaksanaan sosial religius Hindu di Bali. Tulisan ini bertujuan untuk dapat menjelaskan konsep Ista Dewata dalam lontar Bhuana Sangkșepa, mengaitkan konsep Ista Dewata dalam Veda dengan lontar Bhuana Sangkșepa serta menjelaskan keterkaitannya dalam pelaksanaan sosial religius Hindu Bali. Tentunya tulisan ini bermanfaat untuk mengedukasi masyarakat dalam menjelaskan keterkaitan ajaran Veda dengan teks lontar Bali terutamanya pada konsep Ista Dewata, serta memberikan sumber pustaka Veda dalam landasan pelaksanaan sosial religius Hindu di Bali. 


\section{METODE}

Tulisan ini menggunakan dua teori yang dipadukan, yaitu teori hermenutika, dan teori interaksionisme simbolik. Teori Hermenutika dengan tiga unsur dalam aktivitas penafsirannya, yaitu (1) tanda, pesan, atau teks yang menjadi sumber atau bahan dalam penafsiran yang diasosiasikan dengan pesan yang dibawa oleh Hermes; (2) perantara atau penafsir (Hermes); (3) penyampaian pesan itu oleh sang Perantara agar bisa dipahami dan sampai kepada yang menerima (Faiz, 2003: 21)2, sedangkan dalam teori interaksionisme simbolik Herbert Blumer ${ }^{3}$ menekankan (1) Manusia bertindak terhadap sesuatu berdasarkan atas makna-makna yang dimiliki benda itu bagi mereka; (2) makna-makna itu merupakan hasil dari interaksi sosial dalam masyarakat manusia; (3) makna-makna dimodifikasi dan ditangani melalui sesuatu proses penafsiran yang digunakan oleh setiap individu dalam keterlibatanya dengan tanda-tanda yang dihadapinya. Kedua teori ini digunakan untuk memahami teks lontar Bhuana Sangkșepa dan pelaksanaan sosial religius Hindu di Bali.

Metode dalam pengumpulan data menggunakan metode simak, yang dikombinasikan dengan teknik dasar catat. Metode simak ini dipilih karena objek yang diteliti berupa bahasa yang bersifat teks (Sudaryanto, 2015:205-206) serta ditambah dengan teknik observasi (obsevasi partisipan) dengan mengamati secara langsung pelaksanaan sosial religius Hindu di Bali. dilanjutkan dengan menggunakan metode dan teknik analisis data yang meliputi (1) Reduksi Data, (2) Penyajian data, dan (3) Verifikasi. Diakhiri dengan metode penyajian hasil analisis data menggunakan metode informal.

\section{PEMBAHASAN}

\section{Lontar Bhuana Sangkșepa}

Lontar Bhuana Sangkșepa secara etimologi kata Bhuana Sangkk̂epa, terdiri dari kata Bhuana, Sang dan kûepa. Kata Bhuwana ${ }^{4}$ dalam kamus bahasa Jawa Kuno-Indonesia berarti dunia, alam, loka dan jagat sedangkan dalam kamus bahasa Sanskerta-Indonesia ${ }^{5}$ kata Bhuwana memiliki pengertian yang hampir sama yaitu sebagai makhluk dunia, jagat raya,

\footnotetext{
${ }^{2}$ Ketiga unsur tersebut menjadi hal utama dalam hermeneutika, yaitu sifat-sifat teks, alat yang dipakai untuk memahami teks, dan bagaimana pemahaman dan penafsiran itu ditentukan oleh anggapan-anggapan dan kepercayaan-kepercayaan mereka yang menerima dan menafsirkan teks.

${ }^{3}$ Blumer H. 1969. Symbolik Interactionism Perspektif and Method.Englewood Cliffs, N.J.: Prentice- Hall, Inc.

4 (Zoetmulder, 2004:145) pada Kamus bahasa Jawa Kuno-Indonesia Cet IV bekerjasama dengan Robson, penerjemah Darusuprapta dan Suprayitna.

${ }^{5}$ Kamus Bahasa Sanskerta-Indonesia oleh Tim penyusun (2000:275). Tim Penyusun yang terdiri dari beberapa tokoh ahli seperti I Gde Sura, I Gde Semadi Astra, IB Gde Agastia, I Wayan Musna, Ni Luh Suiti, I Wayan Cika, I Gusti Ketut Dalem, dan kamus bahasa Sanskerta-Indonesia oleh I Made Surada (2007:244)
} 
dan tempat tinggal. Kata sang ${ }^{6}$ merupakan partikel dalam bahasa Jawa Kuno terdapat didepan kata benda menunjukkan orang dari derajat tertentu. Sedangkan kata kûepa hanya ditemukan dalam kamus bahasa Sanskerta-Indonesia7 memiliki pengertian lemparan, gerakgerakan membanggakan, dan melambungkan. Jadi secara terminologi yang dimaksud lontar Bhuana Sangkûepa dalam tulisan ini merupakan ajaran orang yang mengajarkan konsep alam semesta beserta isinya.

Isi teks Lontar Bhuana Sangkșepa memuat dialog antara Bhațāra Śiwa dengan Bhațāri Uma disertai dengan Bhațāra Kumara. Lontar Bhuana Sangkșepa terdiri dari 128 Sloka bahasa Sanskerta dengan bahasa Jawa Kuno, isinya pada menjelaskan mengenai cara untuk mencapai kalepasan dengan ajaran Yoga. Pertama dijelaskan tentang proses penciptaan yang meliputi ketika tidak ada apa-apa, air, tanah, cahaya, angin, bulan, matahari, angkasa, bintang-bintang pun tak ada. Demikian juga sabda, awan, siang, malam, hujan, kilat dan sebagainya juga tak ada.

Yang ada ketika itu hanyalah śunya belaka yang bersifat kekal abadi atau langgeng. Melalui śunya atau disebut nișkala secara berurut lahirlah matranadānta, nada, windu, ardhacandra, tryakșara, panca brahma, pancākșara, sarwākșara, swara dan wyanjana yang merupakan tubuh para dewa (Ista Dewata). Untuk memahami itu orang patut melaksanakan yoga serta melepaskan pikiran dari objeknya. Pada bagian akhir lontar tersebut, menguraikan tentang sapta loka, sapta patala, sapta samudra, sapta tirtham sapta dwipa, yang terdapat dalam tubuh manusia, beserta nama dewa-dewa. Demikian pula uraian mengenai panca bayu, yaitu prana, apana, wyana, samana, dan udana. Pada bagian akhir lontar ini menguraikan mengenai dewa-dewa nawa sanga dengan senjatanya masing-masing.

\section{Konsep Ista Dewata dalam Lontar Bhuana Sangkșepa}

Ista Dewata adalah perwujudan atau manifestasi Ida Sang Hyang Widhi Wasa dalam berbagai manifestasi-Nya dengan memiliki fungsi yang berbeda-beda dalam menjalankan tugas di alam semesta. Surada (2020:1) menjelaskan Ista Dewata adalah Dewata (para dewa) yang diinginkan hadir pada waktu pemuja memuja-Nya. Ista Dewata adalah perwujudan Ida Sang Hyang Widhi Wasa (Tuhan) dalam berbagai wujudnya seperti Brahma, Wisnu, Iswara, Mahadewa dan sebagainya.

\footnotetext{
${ }^{6}$ Zoetmulder (1992) pada buku bahasa parwa I menyatakan penggunaan kata sang dipakai untuk orang ternama atau bangsawan.

${ }^{7}$ Lihat Kamus Bahasa Sanskerta-Indonesia oleh Tim Penyusun (2000:143) dan kamus bahasa Sanskerta-Indonesia oleh I Made Surada (2007:244)
}

132 | SPHATIKA: Jurnal Teologi Vol. 12 No. 2, September 2021 
Ista Dewata yang beragam wujud dan fungsi, tentunya menyebabkan mantra atau puja-Nya (Stava) juga akan beragam sesuai dengan Dewata yang dipuja. Surada (2020:1) menjelaskan misalnya pada hari suci Saraswati, maka Ista Dewata yang dipuja adalah Dewi Saraswati dengan mantram atau puja (Saraswati Stawa). Puja yang dilantukan kepada Ista Dewata, sesungguhnya berasal dari bahasa Sanskerta yaitu puj dengan urat kata kerja kelas X yang berarti menghormat, memuja, atau memuji (Surada, 2020:1). Jadi kata Puja Ista Dewata adalah menghormati melalui pujaan dan pujian kehadapan Ida Sang Hyang Widhi Wasa atau Ista Dewata (Dewata yang diinginkan hadir).

Konsep Ista Dewata mulai dijelaskan pertama dalam lontar Bhuana Sangkșepa ketika tidak ada apa-apa, air, tanah, cahaya, angin, bulan, matahari, angkasa dan bintang-bintang tidak ada. Yang ada hanyalah sunya yang bersifat kekal abadi. Kemudian dari sunya yang disebut pula niskala secara berturut-turut lahirlah : Matra - Nadanta - Nada Windu Ardhacandra - Tryaksara - Pancabrhma - Pancaksara - Sarwa Aksara - Swara dan Wyanjana yang merupakan tubuh para Ista Dewata, seperti : 1. Iswara di timur; 2. Mahesora di tenggara; 3. Brahma di selatan; 4. Rudra di barat daya; 5. Mahadewa di barat; 6. Sangkara di barat laut; 7. Wisnu di utara; 8. Sambu di timur laut; 9. Siwatma di (tengah) bagian bawah; 10. Sadasiwa di (tengah) bagian tengah; 11. Pramasiwa di (tengah) bagian atas; 12. Dharma diantara timur dan tenggara; 13. Kala diantara tenggara dan selatan; Mretyu diantara selatan dengan barat daya; 14. Krodha diantara barat daya dengan barat; 15. Wiśwa diantara barat dengan barat laut; 16. Kama diantara barat laut dengan utara; 17. paśupati diantara utara dengan timur laut; dan 18. Satya diantara timur laut dan timur.

Adapun kutipan konsep Ista Dewata dalam teks lontar Bhuana Sang Ksepa, sebagai berikut.

Iśa urvantu vijńeyah, Agneye tu māheśvarah, Brahmāi i dakṣinajneyah, Nairityam rudra evaca. Paścimanta māhadevah, Vayabhyam sangkaras tatha, vișnu utțara vijńeyah, airśamyam sambhur evaca. Adohara itijneyah, Madhyo cā $i$ sadaśivah, Urde aramaśivā i, Iti devo ratișțitah. Dharma kālańca mrtyuńca, Krodha viśvakāmastatha, Pasu atiśca satyaśca, ratiștha maratoudạ

Terjemahannya:

(Bhuwana Sangkșepa Sloka 11-14).

Demikianlah dewata yang membuat hidup dalam hati. Iśa di timur. Mahesora di tenggara. Brahma di selatan. Rudra di barat daya. Mahādewa di barat. Sangkara di barat laut. Wiṣnu di utara. Sambhu di timur laut. Śiwātma di bawah. Sadaśiwa di tengah. Paramaśiwa di atas. Dharma di antara timur dengan tenggara. Kāla di antara tenggara dengan selatan. Mrêtyu diantara selatan dengan barat daya. Krodha diantara barat daya dengan barat. Wiśwa diantara barat dengan barat laut. Kama di antara barat laut dengan utara. Paśupati diantara utara dengan timur laut. Satya diantara timur laut dengan timur. 
Berdasarkan kutipan teks lontar Bhuana Sangkșepa tersebut dapat dipahami bahwa segala arah mata angin terdapat stana dari para dewa atau Ista Dewata yang merupakan manifestasi dari Sang Hyang Widhi Wasa. Di Bali ada konsep yang sering dijelaskan para tetua (panglingsir) terdahulu yaitu "Bhatara Ngyangin Ring Sahananing Genah atau Bhatara Sarwa Ngyangin" yang artinya Tuhan berstana (menempati) pada setiap tempat di alam semesta (bhuana agung dan bhuana alit). Konsep Bhatara Sarwa Ngyangin berkorelasi dengan isi teks lontar Bhuana Sangkșepa yang menjelaskan Ista Dewata berada pada arah mata angin, arah mata angin menunjukkan segala tempat diliputi oleh kemahakuasaan Tuhan, Tentunya ini mengkontruksi pemahaman masyarakat Hindu di Bali dengan selalu menunjukkan aktivitas sosial religius dengan melakukan yajna atau persembahan melalui menghaturkan sesaji pada sebuah tempat, baik secara nitya karma maupun naimitika karma. Tuhan berada dimana-mana atau dalam bahasa Jawa Kuno atau Kawi dikenal dengan Wyapi-Wyapaka Nirwikara, Realitas ini selaras dengan esensi ajaran Śiwa tattwa yang menyatakan Tuhan (Siwa) berada disegala tempat, maka dapat dikatakan bahwa realitas yang ada di alam semesta dan dunia ini adalah Tuhan. Dalam pustaka Candogya Upanisad III.14 menegaskan bahwa:

"Sarvam khalv idam brahma, tajjalan iti santa upasita; atha khalu kratumayah purusah, yatha kratur asmini loke puruso bhavati tathetah pretya bhavati, sa kratum kurvita" Terjemahannya:

"Sesungguhnya seluruh jagat ini adalah Brahman (Tuhan), dari mana dia datang kemana-mana, tanpa siapa dia dihancurkan dan dimana dia bernafas. Dalam ketenangan seseorang semestinya Samadhi atas hal ini. Sekarang sesungguhnya seseorang berada di dunia karena suatu tujuan. Sesuai dengan tujuan yang dimiliki seseorang dalam dunia ini, demikian juga dia meninggalkannya. Karena itu biarkanlah seseorang merangkai tujuan untuk dirinya" (Radhakrisnan, 2008: 300).

Kutipan pustaka Candogya Upanisad III.14 menjelaskan bahwa seluruh alam ini adalah Tuhan dan kemahakuasaan Tuhan hanya dapat dipahami melalui samadi. Segala bentuk tujuan bermuara pada kemahakuasaan-Nya dan manusia diharapkan mampu merangkai tujuan dalam dirinya yaitu untuk bisa menyatu kembali pada Beliau Sang Pencipta. Pemahaman akan Dewa-Dewa atau Ista Dewata merupakan dasar untuk melaksanakan smaranam "konsentrasi". Disebutkan pula bahwa kualitas dari semua aksara adalah pancaksara. Kualitas pancaksara adalah Tryaksara. Dan kualitas dari Tryaksara adalah OmKara yang merupakan sarana untuk mencapai kalepasan dan menghubungkan diri pada Ista Dewata. Segala sesuatu yang ada di atas dunia ini bersifat tidak kekal, karena pada akhirnya semua akan lenyap dan kembali pada akasa. Kelenyapannya secara berturut-turut dijelaskan sebagai berikut: 
a) Bhatara Kama lenyap menjadi Wisnu; b) Bhatara Wisnu lenyap menjadi Krodha;

c) Bhatara Krodha lenyap menjadi Mretyu; d) Bhatara Mrety lenyap menjadi Kala;

e) Bhatara Kala lenyap menjadi Dharma; f) Bhatara Dharma lenyap menjadi Sathya;

g) Bhatara Sathya lenyap menjadi Pasupati; h) Bhatara Pasupati lenyap menjadi Brahma; i) Bhatara Brahma lenyap menjadi Wisnu; j) Bhatara Wisnu lenyap menjadi Iswara; k)Bhatara Iswara lenyap menjadi Rudra; 1) Bhatara Rudra lenyap menjadi Mahadewa; m) Bhatara Mahadewa lenyap menjadi Purusa; n) Bhatara Purusa lenyap menjadi Siwa; o) Bhatara Siwa lenyap menjadi Nirbhana; p) Nirbhana lenyap menjadi Nirasraya (Dunia, 2009:47-48).

Setelah semuanya lenyap maka itulah jalan untuk menuju Nirbhana. Nirbhana itu letaknya tidak jauh, namun juga tidak dekat. Tidak diluar, namun juga tidak di dalam. Tidak diatas dan tidak juga di bawah. Ia ada di mana-mana. Ia adalah perwujudan sepinya sepi, gaibnya gaib. Untuk itu orang harus melaksanannya yoganindra serta membebaskan pikiran dari obyeknya. Disamping itu juga dijelaskan mengenai Saptaloka, Saptapatala, Sapta Sagara, Sapta Tirtha, Sapta Dwipa, dan keberadaannya dalam tubuh manusia yang berkaitan dengan konsep Ista Dewata.

\section{Pelaksanaan Sosial Religius Hindu di Bali}

Pelaksanaan sosial religius Hindu di Bali sangat identik dengan tradisi Veda. Adnyana (2020) menjelaskan konsep ketuhanan dalam Veda mempercayai dewa-dewa, mempercayai leluhur dan memiliki kedudukan tersendiri di alam para dewa (Rg Veda X.15), leluhur pergi kesorga ataupun neraka berdasarkan karmanya, leluhur tinggal bersama para dewa, leluhur ikut minum soma bersama para dewa, leluhur ikut menikmati persembahan dan kedudukan leluhur sama dengan dewa. Konsep ketuhanan dalam Rg Veda adalah percaya kepada Tuhan Yang Maha Esa tetapi juga percaya kepada banyak dewa dengan segala manifestasinya (Kundra dalam Phalgunadi, 2010:17). Ritual dalam Rg Veda sangat jelas tergambar dalam Rg Veda I.162.21-22 yang mengambarkan bahwa penggunaan binatang dalam upacara dan Rg Veda (X.15.14) juga menjelaskan terkait dua jenis upacara kematian yaitu dengan jalan dibakar (agni dagdha) dan dikubur (anagni dagdha), selain itu Rg Veda juga mengajarkan pelaksanaan yajna kepada leluhur (Adnyana, 2020).

Singkatnya kharakteristik zaman Veda, memiliki ciri-ciri bahwa; a) percaya adanya banyak dewa, tetapi juga percaya kepada Tuhan Yang Esa (Monotheisme); b) percaya adanya leluhur; c) pentingnya pembacaan kitab suci Weda (gìtā); d) pentingnya melaksanakan 
upacara yajna kurban; e) pentingnya melaksanakan upacara kematian; f) pentingnya kedudukan pendeta g) agama Weda bersifat optimistik, agama rasa, agama kepuasaan hati, dan bhakti (Adnyana, 2020). Kharakteristik dan tradisi Veda sudah membumi di tanah Nusantara, terkhususnya Bali. Pembumian Veda itu dapat ditinjau dari pelaksanaan sosioreligius Hindu di Bali terkhususnya pada konsep Ista Dewata. Sebagaimana dalam pustaka Veda dijelaskan Ye devaso divy ekadasa, stha prthivyam adhy ekadasa stha, apsuksito mahinaikadoja stha te, devaso yajnamimam jusadhvam "wahai para dewa (33 dewa), sebelas di surga, sebelas di bumi dan sebelas di langit, semoga Engkau bersuka cita dengan persembahan suci ini". Kutipan teks tersebut menjelaskan bahwa dalam Veda dinyatakan ada 33 dewa yang terbagi sebelas pada surga, bumi dan langit. Lebih lanjut dalam $\operatorname{Rg}$ Veda I.52.2 dijelaskan berkaitan dengan kerahasian konsep 33 Dewa, sebagai berikut.

Srustivano hi dasuse deva agne vicetatasah,

Tan rahidasva girvanas trayastrimsatama a vaha

Terjemahannya:

Ya Tuhan Yang Maha Esa, Engkau adalah guru agung, penuh kebijaksanaan, mengaanugerahkan karunia kepada mereka yang mempersembahkan karyakaryanya. Ya Tuhan yang penuh cahaya gemerlapan, semogalah para pencahari pengetahuan rohani dapat mengetahui rahasia dari 33 dewa (yang merupaakan tenaga kosmos).

Dalam pustaka suci Atharva Veda, dijelaskan;

Yasya trayastrimsad deva ange sarva samahitah,

Skambham tam bruhi katamah videva sah.

Terjemahan:

Siapakah yang demikian banyak itu, ceritakan kepadaku, tidak lain adalah

Tuhan Yang Maha Esa yang meresapi segalanya, yang pada diri-Nya dikandung

seluruh 33 dewa (sebagai kekuatan alam)

Yasya trayas trimsad devasange gatra bibhejire,

Tan vai trayastrimsad devaneke Brahma vido viduh

Terjemahan:

(Atharvaveda X.7.27)

Tiga puluh tiga dewa menyelesaikan tugasnya masing-masing, di dalam ciptaan Tuhan yang maha esa. Hanya beberapa orang yang terpelajar di dalam veda memahami 33 devata. Jumlah 33 dewa tersebut mempunyai fungsi masing-masing dalam hubungannya dengan kehidupan manusia.

Konsep 33 Dewa Veda atau yang dikenal Ista Dewata ditransformasikan kedalam pelaksanaan sosial religius Hindu di Bali dengan pangider-ider atau Dewata Nawa Sangga. Pangider-ider dan Dewata Nawa Sañgga merupakan sebuah konsepsi ketuhanan Ŝaiwasidanta yang ditunjukkan untuk mempermudah manusia dalam memahami hakikat Siwa yang Nirguna. Pangider-ider adalah mandala kosmis yaitu skema yang mewakili keseluruhan 
bagian dari kosmos. Pada mandala ini terdapat satu pusat dan setiap arah memiliki dewanya masing-masing. Semua simpul ketuhanan tersebut sebagai wujud implementasi usaha manusia untuk memusatkan diri kepada Sang Hyang Widhi Wasa.

Selain itu konsep pangider-ider merupakan ideologi untuk menyeimbangkan alam, manusia, dan Tuhan, sehingga Tri Hita Karana tidak hanya dalam tataran konsep, tetapi telah masuk ke dalam praktek pikiran, perkataan dan perbuatan, sehingga mampu menghantarkan manusia untuk mengejawantahkan Tri Kaya Parisudha dalam kehidupan sehari-hari. Pangiderider meyakini Bhatara Ŝiwa memenuhi arah mata angina. Beliau pula memenuhi bhuana agung 'makrokosmos' dan bhuana alit 'mikrokosmos'. Bhatara Siwa juga berada di tengah-tengah, sebagai sentrum kosmos, sedangkan pada setiap arah mata angin Ia mempunyai nama-nama, senjata, warna dan aksara suci-Nya yang (tampak) berbeda-beda.

Pangider-ider sering pula disebut sebagai Dewata Nawa San்ga (sembilan kelompok para dewa). Iswara sebagai Siwa di Timur, Brahma sebagai Siwa di Selatan, Mahadewa sebagai Siwa di Barat, Wisnu sebagai Siwa di Utara, Mahesora sebagai Siwa di Tenggara, Rudra sebagai Siwa di Barat Daya, Sangkara sebagai Siwa di Barat Laut, Sambu sebagai Siwa di Timur Laut, dan Ŝiwa sendiri di Tengah sebagai sentrum alam semesta sebagai penjaga equilibrium (keseimbangan). Dalam lontar "Bhuana Sangksepa", pangider-ider seluruh bagian kosmos dikuasai oleh dewa-dewa. Adapun pangider-ider dalam lontar Bhuana Sangkșepa diantaranya: (1) Iśa (Timur); (2) Brahma (Selatan); (3) Mahādewa (Barat); (4) Wisnu (Utara); (5) Maheśwara (Tenggara); (6) Rudra (Barat Daya); (7) Samkara (Barat Laut); (8) Śambu (Timur Laut); (9) Dharma (di antara Timur dan Tenggara; (10) Kala (di antara Tenggara dan Selatan); (11) Mŗtyu (di antara Selatan dan Barat Daya; (12) Krodha (di antara Barat Daya dan Barat; (13) Wiśwa; (di antara Barat dan Barat Laut) (14) Kama (di antara Barat Laut dan Utara; (15) Paśupati (di antara Utara dan Timur Laut); dan (16) Śatya (di antara Timur Laut dan Timur; (17) Hara (ardhah/bawah); (18) Śādā Śiwa (madhya/tengah); dan (19) Parama Śiwa (urdhah/atas). Sebagaimana seperti pada gambar tabel berikut ini. 


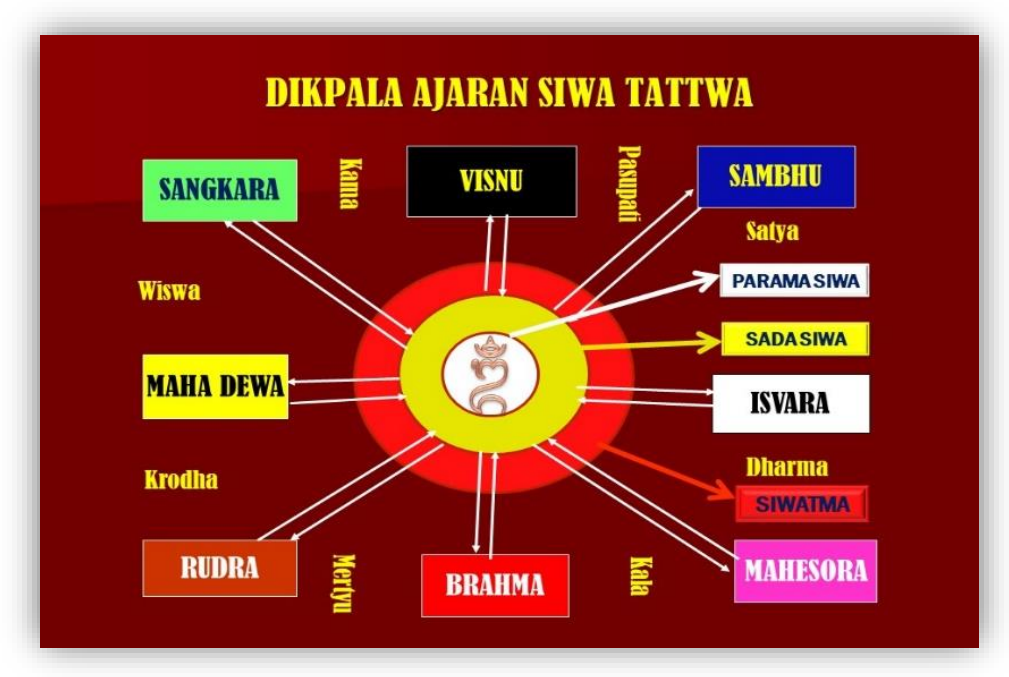

Konsep pengider-ider ini sebagaimana dalam lontar Bhuana Sangkșepa menunjukkan masyarakat Hindu dan ajarannya sangat mengutamakan keseimbangan. Keseimbangan yang selalu dicita-citakan dan dipraktekkan dalam kehidupan sekala 'materi', sekala-niskala dan niskala 'spiritual'. Karena dalam konsep pangider-ider telah menunjukkan suatu mandala keseimbangan. Dari titik zenith atau titik utama (Siwa) menyebar ke seluruh penjuru baik dalam tataran individual maupun dalam dimensi kosmis. Untuk itu, konsep pangider-ider berpengaruh besar terhadap sendi-sendi kehidupan umat Hindu, baik dalam tataran filosofi, etika, dan ritual maupun dalam tataran ideologi.

Bagi masyarakat Hindu Bali, pangider-ider juga memiliki kedudukan penting, pangiderider pada awalnya merupakan konsep ketuhanan yang juga dijadikan ideologi sakralisasi demi terciptanya kerharmonisan. idiologi pangider-ider dapat dijadikan konsep utama terhadap perlindungan lingkungan Bali dari ulah manusia yang tidak bertanggung jawab atas rusaknya eksistensi yang sangat penting bagi eksistensi manusia dan seluruh komponen yang ada pada alam. Pangider-ider sebagai mandala suci yang mengarahkan putaranya ke tengahtengah titik equilibrium (keseimbangan) dan juga ke luar dalam meresapi segala yang ada. Begitu pula warna-warna yang disimbolkan dalam pangider-ider bahwa jika warna-warna yang tampak berbeda dicampur dan diaduk dengan komposisi yang sama, sehingga wujud warna tidak lagi menampakkan karakteristik masing-masing, tetapi di dalamnya masih terdapat warna-warna tersebut. Inilah menunjukkan titik keseimbangan yang membuat keseluruhan perbedaan menjadi netral.

Aksara dalam pangider-ideran dan dewa-dewanya diolah lewat kreativitas jnana dan rasa, sehingga dari aktivitas tersebut dapat mempresentasikan bentuk-bentuk fisik dan ide lebur menyatu dalam kenetralan dan kegirangan abadi. Seperti Dasaksara (Sang, Bang, Tang, 
Ang, Ing, Nang, Mang Sing, Wang, Yang) yang juga dipresentasikan sebagai Dewata Nawasanga. Fenomena tersebut menunjukkan seperti seorang pelukis dalam mencampur beraneka macam warna yang bertujuan untuk menemukan keindahan dalam membentuk sebuah lukisan.

Bagi sosial religius Hindu di Bali, pangider-ideran atau arah mata angin berarti penting, karena diyakini dapat berpengaruh besar bagi segala aspek kehidupan umat manusia dan seluruh komponen alam. Stana Ista Dewata pada pangider-ideran tersebut juga direpresentasikan dalam wujud praktik-praktik acara agama Hindu misalnya seperti pada banten dewa-dewi, sarad, pulegembal, gayah, lis, pembuatan ulap-ulap, rerajahan, dan kajang, serta pada pelaksanaan upacara upakara panca yajna seperti dewa yajňa, pitra yajňa, manusia yajňa, rsi yajňa dan bhuta yajňa. Interaksi simbol-simbol Ista Dewata tersebut yang diaplikasikan pada pelaksanaan sosial religius Hindu di Bali semua saling berpengaruh, berhubungan, dan melengkapi, maka itulah bentuk-bentuk pembumian ajaran Veda yang dapat dilihat pada praktik kehidupan beragama Hindu di Bali. Ibarat keteraturan orbit planet, bintang, asteroid dan lain benda angkasa lainnya di dalam tata surya. Walaupun benda-benda angkasa tersebut melintas pada orbitnya masing-masing, namun seluruhnya saling "terikat" dan saling mempengaruhi.

\section{PENUTUP}

Agama Hindu di Indonesia khususnya yang diwarisi di Bali adalah perpaduan antara keyakinan leluhur (pra Hindu) dengan ajaran Veda yang datang ke Nusantara dan menyatu dengan harmonis membentuk Śivasiddhanta di Bali. Konsep 33 Dewa Veda atau yang dikenal Ista Dewata ditransformasikan kedalam pelaksanaan sosial religius Hindu di Bali dengan pangider-ider atau Dewata Nawa Sangga. Pangider-ider dan Dewata Nawa Sangga merupakan sebuah konsepsi ketuhanan Ŝaiwasidanta yang ditunjukkan untuk mempermudah manusia dalam memahami hakikat Ŝiwa yang Nirguna.

Konsep pengider-ider ini sebagaimana dalam lontar Bhuana Sangkșepa menunjukkan masyarakat Hindu dan ajarannya sangat mengutamakan keseimbangan. Keseimbangan yang selalu dicita-citakan dan dipraktekkan dalam kehidupan sekala 'materi', sekala-niskala dan niskala 'spiritual'. Karena dalam konsep pangider-ider telah menunjukkan suatu mandala keseimbangan. Interaksi simbol-simbol Ista Dewata tersebut yang diaplikasikan pada pelaksanaan sosial religius Hindu di Bali semua saling berpengaruh, berhubungan, dan melengkapi, maka itulah bentuk-bentuk pembumian ajaran Veda yang dapat dilihat pada praktik kehidupan beragama Hindu di Bali. 


\section{DAFTAR PUSTAKA}

Adnyana, Putu Eka Sura. 2020. Karya Prof. Phalgunadi "Sekilas Sejarah Evolusi Agama Hindu": Menelisik dan Memahaminya dalam Bingkai Filsafat Sejarah Hindu pada jurnal sanjiwani filsafat Vol 2, 2020. Denpasar: IHDN Denpasar.

Blumer H. 1969. Symbolik Interactionism Perspektif and Method.Englewood Cliffs, N.J. : PrenticeHall, Inc.

Dunia, I Wayan. 2009. Kumpulan Ringkasan Lontar. Surabaya: Paramita.

Faiz, Fakhruddin. 2002. Hermeneutika Al-Qur'an. Yogyakarta: Qolam.

Ismail, Nawari. 2016. Perubahan Sosial-Budaya Komunitas: Agama Dam. Yogyakarta: CV Budi Utama

Phalgunadi, I Gusti Putu. 2006. Sejarah Evolusi Agama Hindu. Denpasar: Widya Dharma.

Radhakrishnan, S. 2008. Upanisad-Upanisad Utama. Surabaya: Paramita.

Siwananda, Sri Swami, 2003. All About Hinduism (Intisasri Ajaran Hindu)-Penerj. Maswinara, Surabaya: Paramita

Sudaryanto. 2015. Metode dan Aneka Teknik Analisis Bahasa: Pengantar Penelitian Wahana Kebudayaan secara Linguistik. Yogyakarta: Sanata Dharma University Press.

Sura, dkk. 1994. Agama Hindu Sebuah Pengantar. Denpasar : CV Kayumas Agung.

Sura. 1999. Siwa Tattwa. Denpasar: Milik Pemerintah Propinsi Bali, Peningkatan Sarana Prasarana Kehidupan Beragama.

Surada, I Made. 2007. Kamus Bahasa Sanskerta - Indonesia. Surabaya: Paramita.

Surada, I Made. 2020. Beberapa Teks Puja Ista Dewata Dalam Pemujaan Umat Hindu Di Bali. Surabaya: Paramitha

Tim Penyusun. 1995. Bhuwana Sang Kșepa, Sang Hyang Mahājñana, Siwa Tattwa Purāna. Denpasar: Dinas Kebudayaan Provinsi Bali.

Tim Penyusun. 2000. Kamus Sanskerta-Indonesia. Denpasar: Pemerintah Provinsi Bali.

Titib, I Made. 1996. Veda Sabda Suci. Surabaya: Paramitha

Warna, I Wayan dkk. 1991. Kamus Bahasa Bali - Indonesia. Denpasar : Dinas Pendidikan Dasar Propinsi Bali Dati I Bali.

Zoetmulder, P.J. 1983. Kalangwan Sastra Jawa Kuno Selayang Pandang. Penerjemah Dick Hartoko SJ. Jakarta: Djambatan.

Zoetmulder, P.J. 1992. Bahasa Parwa I. Yogyakarta: Gadjah Mada University Press.

Zoetmulder, P.J. dan S.O. Robson. 2004. Kamus Jawa Kuna Indonesia. Penerjemah Darusuprapta dan Sumarti Suprayitna. Jakarta: Gramedia Pustaka Utama. 